\title{
A Social Reformer is peeping through-Sultana's Dream
}

\author{
Syeda Afsana Ferdousi \\ Assistant Professor, Department Of English. niversity OF Information Technology And Sciences
}

\begin{abstract}
The Indo Anglican authoress Begum Rokeya Shakwath Hossain (1880-1932) was born in Pairabandh, village of RangpurBangladesh, is a universal representative as a social reformer. Without any institutional educational background she could set many constructive institutions. She is the founder of Sakhawat Memorial Girl's school, the Bengal branch of Anjuman-i-Khawatin- i- Islam, under whose aegis's women would take up a whole range of activities greater towards social welfare. She wrote a women utopiaSultana's Dream(1905) which has a subtle sense of situational humour, greater observation and scientific knowledge. These all made the creation sound credible. It is a satirical social reforming icon in English to inspire the exiled and education deprived Muslim and the universal women folk for a Renaissance along with a research on women development and suggestions based on personal experiences. Sultana's Dream is a pioneering path shower of women development.
\end{abstract}

\section{Introduction:}

During British Imperialism and colonial rule in India, concern for women development was absent in that society. This social reformist was born in that time in an orthodox and conservative Zamindar (LandLord) family in Pairaband village of Rangpur district. She was confined at home but had a supportive elder brother and elder sister whom we know from her creations especially Abaradh Bashini. There we know how she was guided secretly to learn English and Bengali and communicated with the wider world. Ignorance is the root of all problems which she has learnt from practical life. So she gave emphasis on women education in all her writings.

Fortunately she was married to Khan Bahadur Syed Sakhawath Hossain, Deputy Magistrate in Bhagalpur, who was the inspiration for her and opened a wider world to imply her dream with courageous steps. While editing Sultana's Dream, Sakhawath Hossain mentioned the text 'a terrible revenge' and encouraged and sent to publish it to 'the Indian Ladies' magazine which was later co-edited by Sarojini Naidu, an eminent poetess and published in 1905 in Madras. Later it was published in book form by S.K. Lahiri \& Co., 44 College Street,Calcatta in 1908. Sakhawath Hossain could read Rokeya's dream so he left a fortune of 10,000/ - Rupees for setting up the girl's school.

\section{Renaissance on Women Development:}

Early $20^{\text {th }}$ century women of subcontinent would not think themselves useful for the society. At that time Rokeya founded a girl's school at Baghalpur(1909) but because of family problems she had to leave the place for Kolkata And founded the Sakhwath Hossain Memorial Girl's school (1910)with a few girls who also faced a strong restriction of Borkha(Veils). Many orthodox Muslims were against it but her willpower surpassed all barriers. Beside this she has set income generating projects for middle class women and has helped the slum dwelling destitute women. She has set Moyirun Nisha (Narikuler Shahajja-Helper of the women) to help the distressed women. Rokeya founded the Bengal branch of the Anjuman-i-Khawatin-i-Islam(1916)Today she is an icon for South Asian women to shift them from the darkness to the wider challenging world. Her creation 'Sultana's Dream' is a guideline for the women even the male of the society of the developing countries. Now the guideline is under practice.

\section{Struggle of a reformer:}

Through a minute observation on Sultana's Dream it's clearly identified that it's a path shower of an ideal, hygienic, educated class of generation with aesthetic sense of beauty. It is an example of agriculturally developed, scientifically modern generation as an idol to be copied. This feminist utopia by Rokeya has become the pioneer observer of all basic problems of that contemporary society. As a social worker she has dedicated her life especially after the death of her babies and the tragic death of her husband, where there was no place for her own recreation. In a letter on $19^{\text {th }}$ of August 1915 to Marium Rashid she wrote she could not take any personal time because she dedicated her life for the development of the society. She got a great response from different class of women as in her another letter to Marium she mentioned that a lady gave her ring as fees for this cooperative society. She was upset because the women of Aligar were to set a women university where she was suffering from shortage of money. As she said 'Poor Bangladesh!' It's better not to mention the 
present poverty- If I could get at least two lacs taka I would do something for the distressed women of the country'1 As in 'A Room of One's Own' Virginia Woolf mentioned the barriers of an intellectual woman to be successful are-'Money security and a room of her own'2. She has depicted how did the women of 1860s faced the barriers are clear through the lines from Virginia's 'A Room of one's own'-' Oh, but you know the story ,she said, bored, I suppose, by the recital. And she told me- rooms were hired. Committees met. Envelopes were addressed. Circulars were drawn up . Meeting were held; letters were read out; so- and-so has promised so much; on the contrary, Mr. _ won't give a penny' is the the real picture of the European society of that time as in the subcontinent Rokeya ,here this social worker also suffered from moneylessness. She had the crisis and she tried to manage to solve the problems of the distressed women dedicatedly. And "Sultana's Dream" was her prior thought. In the collection of letters in 'The Essays of Rokeya' (Rokeya Rachanabali) by Bangla Academy her urgency for fund is clear. She had many ideas to imply but shortage of fund caused great hazard . In Virginia Woolf's 'A Room of one's own' she has chronologically portrayed the difficulties even the ladies of Europe faced to raze fund for raising institution for women education. A letter of Rokeya is given below to show the urgency as a social worker to raze fund-

May Allah bless you. ... I am happy to receive processed mango. Bua !I would be more happy if you could send me four or five taka for school fund than sending processed mango .

I have received money from a person of Yangun - He has sent 27taka last month, this month it is 69 taka 6 paisa. But I see you by being so bosom of mine are forgetting my school.

\section{Strong Purda System\& Her Reaction:}

\section{Basic Problems Of Women of That Society:}

'Sultana's Dream' was placed as dream or nap to us where the clues of reformation were hidden. One evening while she was lounging in an easy chair - at her resting time -her subconscious mind is reflected through the dream. She was accompanied by 'Sara'- representative of a reformed modern society, brought out the basic problems of the women of subcontinent where misinterpretation of male dominated social barriers got priority.Her terrible revenge ironically set men under strong 'purdah(Veils)' which were actually man made.

As in The Holy Quran it is clearly written -

And their Lord has accepted of them and answers them: "Never will I suffer to be lost the work of any of you be it male or female: You are members of one another."5

"If any do deeds of righteousness be they male or female and have faith they will enter paradise and not the least injustice will be done to them."6

For Muslim men and women and for believing men and women, for devout men and women, for true men and women, for men and women who are patient and constant, for men and women who humble themselves, for men and women who give in charity, for men and women who fast (and deny themselves), for men and women who guard their chastity, and for men and women who engage much in Allah's praise, for them has Allah prepared forgiveness and great reward"7.

\section{Misinterpretation of male\& Her revenge:}

Men and women are equally important for the development of the generation. Begum Rokeya focused on the misguiding of male of the society where her wroth is reflected as great outburst in her creation "Sultana's Dream." Even in her famous prose "God Gives, Man Robs"7as published in "The Musalman" in 1927 , she discussed ' There is a saying- Man proposes, God disposes' but my bitter experience shows that God gives, Man Robs. That is , Allah has made no distinction in the general life of male female- both are equally bound to seek food, drink, sleep, etc. necessary for animal life.Islam also teaches that the male and female are equally bound to say their daily prayers five times, and so on.' 8

The so called orthodox male of the society, as they got priority of leading the society, misinterpreted and misled the community for their own benefit. It hampered the growth of women as a human being has become an instrument and burden. This satirical note should knock the male so called educated persons who has the responsibilities to make. As she mentioned in her prose -" Our great Prophet has said-" Talibul Ilm farizatu ala kulli Muslimeen-o-Muslimat" (i.e.it is the bound den duty of Muslim males and females to acquire knowledge). But our brothers will not give us our proper share in education"9

\section{Illiteracy and Early marriage , Her initiatives:}

Sultana had a constructive dream where like every other nation this lady land had 'a past history' which was not glorious. The Queen who had the light of education made some rules which reflects Rokeya's thought. She (Queen) ordered -

"No women were to be allowed to marry before she was twenty -one. She circulated order 'all the women in her country should be educated' 
The main two problems of the women of the world are reflected through the order of that ideal Queen. If we analyze the background of Rokeya it's clear through her experience with different class of women she found these basic barriers of the women in India. So she reflected her mind to depict the causes behind. As women were almost half of the society and they were illiterate and the bondage that is set in childhood by setting early marriage causes disaster in their creativity and health so it's a must to stop early marriage and make them educated to make the generation educated. Another social reformer Raja Ram Mohan Roy(17741833), the pioneer of modern Indian Renaissance by introducing Western ideas of liberal democracy and reaffirming his faith in Advaita Vedanta, gave a sense of direction to the course of India's future development. Child marriage, infanticide, purdah system, caste system, drinking and untouchability were in vogue during this period and they were sapping the vitality of India.

As it is told 'give me an educated mother I will give you an educated generation' Early marriage was a common problem in subcontinent. So, women who are burdened with early marriage And many children cannot bear to lead a happy, healthy and creative life because it makes a girl becoming an unhealthy mother and ruin her and the baby's lifetill days. This was common even in early England where Virginia set a character Mary Saton who "Making a fortune and bearing thirteen children - no human being could stand it . Consider the facts, we said. First there are nine months before the baby is born. Then the baby is born. Then there are three or four months spent in feeding the baby. After the baby is fed there are certainly five years spent in playing with the baby. You cannot, it seems, let children run about the street' 11 So actually the whole creative part of a women are spoiled.

According to Islam, (the religion Sultana stick to), the actual view of that religion gave equal emphasis on men and women on education .

As education is not only a right but also a responsibility of all male and female, Prophet Muhammad(SM)said:

"Seeking knowledge is mandatory for every Muslim(male and female) ${ }^{4}$

According to Hadis of Islam 'You can go even to China to acquire knowledge.'-that shows you should strive to gather knowledge. Beside this in The Holy Quran it is clearly written that Men and women have the same religious and moral duties and responsibilities. They both face the consequences of their deeds.

\section{Ironical Setting of male dominated society For reformation:}

Here to attack the male dominated society she has set male in female's stand. This is most witty work of a wise reformer. As in 'A Room of One's Own' Virginia Woolf has set 'Jodiath Shakespeare' an imaginary sister of Shakespeare to show though she had the geniuses like 'Shakespeare' yet she had to face tragic ending because the European society did not give her the freedom to flourish-there were lots of barriers that she had to struggle with .Mrs. R.S. Hossain had to take shelter of dream to establish her Utopia. A confined woman like her could do nothing than taking shelter of the dream. Her intention could get a shape because of this.So, she hold the hand of a lady who at first seems sister then friend and ultimately unknown representative of a successful country where women could establish their position logically.

In 1908 'The Musalman " published a criticism on Sultana's Dream" -'This is a booklet written in English by Mrs. R. S .. Hossain . Sultana, an imaginary character, is attributed a marvelous dream in which she was transported to an imaginary land ruled by a female sovereign where peace and happiness reign supreme. The male members in that imaginary land discharge the functions of women in the real world. , and the women do those of men. The conception is very ingenuous hit at the Purdah system prevailing in Here to attack the male dominated society she has set male in female's stand. This is the Mohamedan world. We have found a genuine pleasure in the perusal of the booklet. It seems to us that Mrs. R.S. Hossain -the able authoress is a lady of whom any nation may be proud"10

According to Rokeya the qualities of women could not get further room because the male intention did not allow women in most of the cases though she was lucky enough to get all the supports of male to establish herself. Sultana talked about her experiences in lady land.

Sultana utters-

"I was feeling very shy, thinking I was walking in the street in broad day light, but there was not a single man visible.

Some of the passers - by made jokes at me."

This actually shows the men of the society who through 'eve teasing' destroys much creativity of the women folk and abolishes the development of the society as they are the half of the manpower of the society. Now law is set to protect the creativity of a woman that they won to prove the qualifications they earned through their research work. 


\section{Positive thinking on Patriotic Agricultural Reformation:}

The aesthetic sense of the citizen made the land heavenly as we see in the lady land. As the ideal lady in 'Sultana's Dream' says-

"This is lady land free from sin and harm. Virtue herself reigns here"

The 'lady land' looked like a 'garden'. As Sultana said-

"You have arranged every plant skillfully"

In answer to it Sara said:

"Your Calcutta could become a nicer garden than this if only your countrymen wanted to make it so"-

This reflects her inner mind where the hopeful attitude of a social reformer reflects. An encouraging note of Sultana that it's not impossible to make a country like 'garden' if willpower is positive.

She observes that 'Horticulture' is a science and if the social workers apply this science by giving emphasis on agricultural development it will work. Ethical, Infrastructure can prove a nation sophisticated. In her writing all sorts of developments are discussed. These all seems as proposal for the welfare of a country because its' application made lady land heavenly.

\section{Creation of Patriotic, active Manpower:}

'Sara' is an example of an ideal working class as Sultana observed she could manage to do all sorts of works. It's an encouragement for Rokeya's own state. She takes care of office and also does home decoration and even does 'needle work' so she asked Sara to give us a clue how we can manage to be manpower for the society-Sultana asks :

"How can you find time to do all these? You have to do the office work as well?"

She answered:

"I do not stick to the laboratory all day long. I finish my work in two hours".

She criticized the officials (men) of our society who lingers two hours work into seven to eight hours to show they dwindle away their time in various unproductive activities. As they talk much about their work, but do little'. She set a calculation of time they are wasting:

"Suppose one choroot takes half an hour to burn off and a man smokes twelve cheroots daily; then you see he wastes six hours every day in sheer smoking"

This is a real picture of our officials which they cannot deny. This logical and constructive attack of a feminist writer to criticize men of the society so that they change their mentality.

\section{Feminist outburst:}

Rokeya set those nightmarish activities practically to attack the men of the society who are now confined in 'zenana' willingly. When the absence of men is marked by Sultana,Sara replied that they are in their 'proper place, they ought to be'. She then explained that all men or zenana are inside so women are free to move around she gave the example:

If some lunatics escape from asylum naturally they will not be allowed to roam about doing mischief but should be sent back to the asylum. As Sultana felt its difficult in their land because men are stronger than women, then Sara corrects her :

"A lion is stronger than a man, but it does not enable him to dominate the human race. You have neglected the duty you owe to yourselves and you have lost your natural rights by shutting your eyes to your own interests".

Through this animal image Rokeya satirized the male dominated society and the avoidance and acceptance of this kind of crimes in this present world. Her wroth against these characters are very crude as she treats them bitterly. As a feminist utopian representative Begum Rokeya always wanted to guide and show right path to the women folk.

\section{Potrays a Healthy and Hygienic Modern Society:}

Mrs. Rokeya has brought out all sides to reform a society. She gave clues how to maintain a healthy and hygienic environment. The actual condition of a kitchen on a Bengali environment is depicted nicely in Syed Mujtaba Ali's 'Rashanai Bilash' where he mentioned that kitchen is the most dirty place, very unhygienic .People are busy to cook spicy dishes in Bengali kitchen in our society which is felt by a reformer like Rokeya. She tactfully portrayed a picture of an ideal kitchen through Sara. An ideal kitchen should have cleanliness; a beautiful vegetable garden can give us environment to prepare healthy fresh food. 'Smoke of kitchen causes many diseases like asthma and other diseases. So, modern form of cooking was her prescription through her imaginative observation where the use of 'solar heat' gave a new idea among the generation of that time. The implementation of solar heat is now one of the latest inventions of modern science.

“How do you cook?' I asked

With solar heat' she said." 
She tactfully, with scientific method, has set the imagination (dream) as true (real).

This idea can set a newer world where every sector for the welfare of human being gets priority which is act of an organized reformer.

\section{Research based Education for the reformation of the society:}

Rokeya is a modern reformer as her presentation on topics is modern. She has presented the implementation of education on everyday need and for the welfare of the generation. Science for life and research on various need of our world can be set by a resourceful research- as various kinds of inventions like steam engine, paper, wheel etc. made our life modern and easy so if our university wits dedicate themselves and their intellect for some resourceful activities as in 'Sultana's Dream' it would be the best gift for the generation. She has set a practical example though a little imaginative, yet she gives some logical clues like- to store rain water as resource. By using 'captive balloon 'to restore water and recycle the environmental resources to protect and save us from different types of calamities which the people of this continent seldom face. She gave the clue to restore water and control the country's hot weather by setting shower of rain from the water balloon. The research was done in one Women University where in other Women University they tried to do some more extraordinary thing . Her concept of a university is much modern as she portrayed there should have research and decorated with some of their manufactories, laboratories and observatories. It is also a clue for today even. They invented solar panel and stored power for further need. The Queen set men powerless who were misusing power by using unnecessary destructive military power. These unproductive men are none but the critics of the society who had only physical power to misuse and who only laughs at some noble deeds as here they criticized the women's research as "a sentimental nightmare."But women folk raised head to protect the country by using solar power in the battle field. The lady Principal with her two thousand students marched and used the rays of the concentrated sunlight and heat towards the enemies and fled away. The men promised to be inside 'zenanapordah' before if the ladies could save the country. So the lady land became free from 'sin and harm'. Though it seems childish yet it's an outburst of the suffering class whose suppressed wroth is reflected through the crude experiences Rokeya faced by becoming a social reformer of that male dominated society.

\section{Implementation of successful leader:}

A true leader with patriotic feeling can have better initiatives to present the generation a successful country. In 'Sultana's Dream' she has presented a most cordial Queen (ruler) with the subjects where leadership prevails for the welfare of the citizen. Though ruled by a queen with the setting of imperialistic culture yet she never thought her the ruler, she represented as the one of the citizens as in The Gulliver's Travels -'A Voyage to the Brobdignag'-the king is a learned person and he feels he is not a ruler but a helper for the citizen. The turmoiling situation of the contemporary political condition of the early $20^{\text {th }}$ century disturbed the development which as a social reformist Rokeya had to face.A learned and patriotic leader can change the country into a garden as through example she has set that thirty years back that lady land was like our country but the intention and quality of the queen made the country an ideal abode. So as a social reformer Rokeya is optimist and set this "Utopia" through it a true social reformer peeps.

She criticized the political stand of the colonizer as according to the Queen -"we do not covet other people's land,we do not fight for a piece of diamond though it may be a thousand-fold brighter than the KohiNoor,nor do we grudge his Peacock Throne."This shows her hatred against the colonizers of the contemporary India.

\section{Modern concept on trading:}

In that imaginary land 'the lady land' the commerce is having a modern concept-free trading. As when Sultana was talking to the queen she mentioned -'The Queen told me that she had no objection to permitting her subjects to trade with other countries' But she was strict with the rule and honesty so she says-'No trade was possible with countries where the women were kept in the zenanas and so unable to come and trade with us. Men, we find, are rather of lower morals and so we do not like dealing with them.'

\section{Humanism:}

An ideal country should not have any conflicts as in lady land they don't have any conflicts . Every social workers are humanists. Sultana also talks of a religion 'based on truth and love' In lady land the treatment on human is liberal as she said-'It is our duty to love one another and to be absolutely truthful.' There is no punishment like 'killing creation of God, especially a human being'. The punishment is set intellectually as a human being we are the best creation. 


\section{Conclusion:}

Through this suggestive literary work Sultana gave a guideline to the contemporary society people. Not only a feminist or an educationist here she is an icon for all sort of reformations for an ideal society. Through parallel setting of developed and developing society Mrs.Rokeya could arise dream or hope among the up coming generation. This was an initiative to project on the guidelines as literally set in her creation Sultana's Dream. Observation and vision through experience could set modern concepts for the welfare of an ignorant, illiterate ,misguided women of subcontinent.

\section{Work cited:}

[1]. Racanabali, Rokeya Pg 500, letter to Marium Rashid on $5^{\mathrm{TH}}$ January, 1926

[2]. Wolf Virginia A Room Of One's Own' Cambridge University Press,edited by Jenifer Smith

[3]. Racanabali, Rokeya Pg 503, letter to Mohsena Rahman ON 21.5.1929.

[4]. (Qur'an3:195)

[5]. (Qur'an4:124)

[6]. (Qur'an33:35)

[7]. Rokeya Begum, Prose 'God Gives Man Robs'- Racanabali, Rokeya Pg_628

[8]. (Qur'an42:11)-first line

[9]. Rokeya Begum, Sultana'S Dream and Padmarag, Penguine Books, India,2005

[10]. Swift, Jonathan- Gulliver'S Travels, Penguine Books, India, 1977.

[11]. www.wekipedia 